\title{
THE IMPACT OF MARKETING INNOVATION ON THE COMPETITIVENESS OF ENTERPRIS- ES IN THE CONTEXT OF INDUSTRY 4.0
}

\author{
- Otakar Ungerman, Jaroslava Dedkova, Katerina Gurinova
}

\begin{abstract}
Marketing innovation is identified as a search for creative and new solutions to problems and needs. For businesses to become more competitive and improving their performance, they must constantly develop new products as well as strategies. This paper is based on the research of areas of marketing in the context of Industry 4.0 and its impacts. The implications of digitization are the content of the research presented here. On the basis of the research, a pilot research was carried out among 50 enterprises that present themselves using Industry 4.0. A list of 15 basic tools of marketing innovation was compiled through an evaluation using the content analysis method. Eleven main impacts of marketing innovation which the respondents consider to be important were then generated. These impacts were described and subsequently evaluated using descriptive statistics methods, on the basis of which their importance was empirically verified. The impacts that businesses classed as being most important were: increasing the competitiveness of the company, increasing work productivity and changing the corporate culture. The results of the research showed that there are differences in how impacts are seen by SMEs and by large enterprises. The impacts are rated as most important by enterprises from the automotive industry with a European corporate culture. The research has empirically confirmed that businesses consider the greatest impact of innovative marketing in the context of Industry 4.0 to be the increase in enterprise competitiveness, which was the highest rated impact of the research. The paper has shed fresh light on our current understanding of innovation as a factor in competitiveness.
\end{abstract}

Keywords: competitiveness, innovative marketing, industry 4.0, digitalization, impact of marketing innovations JEL Classification: $M 31$

\section{INTRODUCTION}

In times of globalization, businesses face rapid changes both in customer needs as well as in the nature of the markets. In order for companies to gain a competitive edge and improve their performance, they have to develop new products and strategies to attract new customers and satisfy existing ones. That is why the notion of innovation, which moves a company forward, is now becoming more important. Innovation can generally be characterized as creating something new, not yet existent, which potentially has the ability to attract a customer's attention (Pitra, 1997). In the Czech Republic and the European Union, data on innovation is investigated through the CZSO statistical survey every two years. The content of the research is based on a methodological manual called the Oslo Manual from the year 2005. According to this paper, innovation can be separated into four groups: product innovation, process innovation, organizational innovation and marketing innovation (OECD, 2005). These four innovation groups are further divided 
into technological and non-technological. Technological innovations include product and process innovation, and non-technological ones include marketing and organizational. This paper deals with non-technological marketing innovations.

Suraksha (2016) conducted research showing the link between marketing innovations in an enterprise and an increase in the competitiveness of the brand or retailer. This study also recommends that information should be pooled and used by both the purchaser and the seller to ensure better implementation of innovations. In their paper, Kamp \& Parry (2017) proved that modern innovative marketing has a beneficial impact on boosting sales and reducing costs, thus improving competitiveness. Innovations in enterprises, which are linked to the gradual implementation of digitization, have recently taken on turbulent speed. The current digitization is the content of the Industrial Revolution called "Industry 4.0". Wang at al. (2016) claim that an enterprise applying Industry 4.0 is better at meeting customer needs in terms of product functionality, quality and service life, which makes the enterprise more competitive. While the expected impacts of this revolution will affect the entire society, the crucial question for this article was what impact companies predict in the area of innovative marketing.

The main aim of the paper is to identify the impacts of innovative marketing on enterprises' competitiveness in the context of Industry 4.0.

Sub-objectives of the contribution:

- To determine the importance of the identified impacts of implementing marketing innovations.

- To compare the answers to the classification questions that dealt with the size of the enterprise, the field of business, and geographic business culture.

All of the objectives are fulfilled through a pilot primary research, which is part of a project dealing with current business marketing trends.

\section{LITERATURE OVERVIEW}

Prior to launching the pilot research, a thorough review of scientific databases and scientific literature was carried out. The research was devoted to two areas: marketing innovations and the impact of innovation in enterprises.

Marketing innovation must be part of a marketing concept and strategy that is significantly different from the original marketing methods. Marketing innovation is based on the understanding that adhering to existing marketing rules alone is not enough to ensure success and competitiveness in crowded markets. (Kotler, 2005) Marketing innovation is based on lateral thinking, of which the principle is playfulness, boundlessness, and provocativeness. The areas of marketing innovation have a progressive development, including personal marketing, ambient marketing, environmental marketing, guerilla marketing, ambush marketing, buzz marketing, viral marketing, product placement, mobile marketing, even marketing, word of mouth marketing, neuromarketing, geomarketing, behavioural marketing and more. These new areas are rapidly emerging, and their definitions and breakdowns are often uneven. (Chuwiruch, Jhundra-Indra, \& Boonlua, 2015) Many authors such as (Son et al, 2012; Prahalad \& Ramaswamy, 
2004; Magrath \& Higgins, 1992) agree on the division of innovative marketing into six core areas: 1. Innovation based on key technologies - using key technologies brings new and different products. 2. Innovation based on the unique transport of common controls, 3. Innovation that meets the unmet needs of customers, 4. Innovations created from pure imagination - often this type of innovative marketing continues in creative activities. 5. Innovation based on scientific research and 6. Innovation based on functional excellence. In the final summary, the authors agree (Muangkhot \& Ussahawanitchakit, 2015; Moreira et al., 2012; Kleindl et al.1996; Cummins et al., 2000; Özen \& Bingöl, 2007) and define marketing innovation as doing something fundamentally new with ideas, products, services, or technologies based on market-based ideas that stem from a variety of customer desires. Innovative marketing is the subject of other research. In his work entitled "Průmysl 4.0: výzva pro Českou republiku" ("Industry 4.0: A Challenge for the Czech Republic"), for example, Mař́k (2016) states that innovations are linked with the analysis of big data. This comprises internet image and text data, data collected from autonomous vehicle control systems, i.e. combined multimodal data, medical, business, and financial data, and data from sales of products. Chen, Huang \& Chia (2017), who specialise in marketing in the field of medicine, explored the functions offered by innovative marketing. The authors claim that innovative marketing is based on six functions, which are: product design or packaging, product placement or channel of communication, product promotion or pricing, approach to market, product delivery, service delivery. The examples they give of these functions are the use of applications, the use of social media and opening up processes to customers.

The second part of the research consisted of impacts arising from the implementation of marketing innovation in enterprises associated with Industry 4.0. The President of the International Association of Labor Agencies Ciett \& Muntzová (2016), representing work agencies from more than 40 countries, says that with the arrival of Industry 4.0, mainly people who are engaged in automation work will lose their jobs. It is not just the workers in the assembly-line production, but all who work in a routine manner. However, she claims that massive unemployment is not on the horizon. Indeed, this will create a number of new positions in services or in industries where custom-made goods are needed. According to the chairman of the Czech-Moravian Confederation of Trade Unions J. Středula, up to $40 \%$ of jobs are threatened. Sojková (2017) says that digitization will pose a serious threat to $10 \%$ of jobs over the next 20 years, and that significant changes in the work done will occur in 35\% of jobs. According to the experts from the CzechGerman Chamber of Industry (ČNOPK 2016) which has long dealt with Industry 4.0, the implementation of Industry 4.0 will lead to a dramatic increase in labour productivity. In the next decade, there will be a complete interconnection of the production process, including development and after-sales service. Machines will be controlled by themselves, using sensors, readers and cameras. Robots will automatically report to maintenance staff for revision. The production process will be completely accelerated and refined overall, and production productivity will increase overall. (Korbel, 2016) Distribution channels will be shortened, it will be enough to issue a production order that the company receives from the customer and the machines will report for work and perform the work themselves. A major role in this communication is played by the Industrial Internet of Things, which will connect households to the Internet. The impacts of Industry 4.0 can be seen in the exponential growth of data, called Big Data. Just using information and communication technology helps businesses in their management increase their competi- 
tiveness, and drives businesses toward a higher quality in their activities. Jáčová, \& Horák (2015) and Hommerova \& Patrovsky (2017) state that big data is also significant in corporate CRM, helping to maintain long-term customer relationships. It is possible to process massive data using marketing, which leads to a better understanding of customer needs and more accurate targeting of the marketing strategy. Another basic source of data is social media (Ungerman \& Dědková, 2017; Novotová, 2017). The President of the Czech-German Chamber of Industry Fischer (2017) mentioned that not only the technology needs changing in companies but also the way of thinking. This is due to the pressure on innovation speed, when the response time to market changes will be completely redefined. The impact of innovative marketing associated with Industry 4.0 can be divided into three parts (MPO, 2016):

- Horizontal integration (value chain) - full computer integration of all activities in the enterprise, ensuring everything from order placement through supply chain, development and production to shipping and distribution network.

- Vertical integration - from the lowest level of real-time machine control (with responses in the tens of milliseconds) through the planning out and scheduling of production and ERP systems (enterprise resource planning) to decision-making at the highest level.

- Integration of engineering support (product life cycle) across the entire engineering chain - from research, development, prototyping, and production scheduling to the engineering treatment of the whole product life cycle.

According to the Czech Statistical Office (2016), 20.5\% of enterprises have innovated marketing methods in the Czech Republic. In the framework of marketing innovation, $70 \%$ of these enterprises focused on new media or techniques for marketing communications, $53 \%$ of enterprises on design or packaging, $40.9 \%$ of enterprises introduced new methods for product placement and $21.4 \%$ of enterprises focused on the valuation of products and services. The difference in innovation between large enterprises and small medium-sized enterprises is interesting. Large enterprises placed more emphasis on changes in the design and packaging of products, in total $60.4 \%$ of enterprises, while in small businesses it was only $49.3 \%$. A significant difference was in the implementation of marketing innovations in foreign-controlled enterprises, where $59.1 \%$ of enterprises used more innovative methods of selling and placing products on the market. Domestic businesses have used innovative marketing practices in $37.1 \%$ of cases.

It is interesting to draw a comparison with Denmark, for instance, where Junge et al. (2016) conducted a market survey focusing on enterprises implementing innovations. The majority of Danish firms, $76 \%$, focus on product innovations, $40 \%$ of enterprises carry out process innovations and $13 \%$ of enterprises implement market innovations; the innovations least applied are organizational innovations, in $9 \%$ of firms. Shuba (2016) explored the impacts of innovative marketing on online and offline marketing activities. In his research, he found that thanks to innovations, online marketing surpasses offline marketing by $15 \%$. Online marketing is growing particularly in the field of public relations, while paid online advertising is on the decline. In his research, Shuba also monitored the impacts of innovative marketing on the $4 \mathrm{P}$ marketing mix. The research showed that the biggest change is in product distribution, at 60 $\%$, prices strategies at $20 \%$ and marketing communication at $5 \%$, particularly in advertising. 
Shuba sees the key impacts in changes in the product, amounting to $15 \%$, especially due to the implementation of the IoT. Anna \& Fang (2016) explored the impacts of marketing innovations on customer behaviour. They identified eight fundamental changes to which enterprises and marketing staff should react. The respondents in the research were consumers, and included the following as impacts of innovative marketing: heterogeneity of customer needs, a greater need for customer awareness, market exploitation, market exploration, interfunctional coordination, strategic flexibility, new product performance, technological capability. According to Ghezzi, Balocco \& Rangone (2016), the innovation process includes tools which enable customers to create or configure their own product. These tools are linked to the use of social media and big data. This will result in the product being adapted directly to suit individual customers. On the other hand, innovations in marketing lead to the integration of external problem-solvers with no personal communication. An interesting survey was published by Jeng \& Pak (2016), when they explored the impacts of innovative marketing on enterprises divided up according to their size in the USA. The survey showed that large firms in the USA are prospering far more from the use of marketing innovations. Investments in innovation and marketing by small firms, on the other hand, greatly reduced their performance. Lee et al. (2017), focusing on the impacts of innovative marketing in relation to an enterprise's technological level, conducted research which drew the following conclusions. The research proved that there was a positive link and synergy between the impacts of innovative marketing on enterprises from the high-tech sector. The research demonstrated the positive impacts of both radical and incremental innovations. In contrast, in cases where an enterprise's technological level is low, marketing innovation is not an important factor in increasing the positive effect of incremental innovation activity on a firm's performance. Aksoy \& Cengiz, (2016).

\section{METHODOLOGY}

The main aim of the paper is to identify the impacts of innovative marketing on enterprises' competitiveness in the context of Industry 4.0. In order to meet the stated intention, a high quality and sufficiently broad data base is necessary to analyse the problem in its entire complexity. Due to the fact that the subject studied has not yet been elaborated on the practical level and therefore no specific information is available is an exploratory research that requires paying extraordinary attention to data acquisition. The success of the whole inquiry depends to a large extent on the quality of the data base.

The first step was to carry out a pilot survey as a necessary means for basic orientation in the examined issues and for obtaining elementary statistical characteristics, enabling the subsequent selection of suitable methods and procedures for data processing. The pilot survey was conceived as an intentional selection of 50 enterprises that, according to available information, use marketing innovation in their practice and present themselves through the introduction of Industry 4.0. Since this is not a probability selection, the obtained results cannot be generalized using statistical induction methods. In the first phase, data should be categorized and the investigated phenomena should be characterized through descriptive statistics. A combination of personal and electronic polling was used as a method of data collection. The respondents were submitted a questionnaire on different aspects and issues of marketing innovation. The 
research was, in essence, qualitative, the questionnaire contained mainly open questions, classification questions were included in order to create sub-sets according to the required criteria. The validity of questions is a very important factor which, as a result, influences the success of the entire survey, where piloting is the way to assess the suitability of individual questions, the correct structure of the questionnaire and other factors that substantially affect the quality of the identified data. The reliability of respondents' answers is crucial to gaining credible judgments and conclusions. The respondents did a rating on a six-point scale where $1=$ unimportant and $6=$ most important. Given the nature of the questions, it was necessary to first, sort out the answers, and then, create a reasonable number of categories from their clustering in accordance with them. This process identifies 15 key factors and 11 main impacts of marketing innovation that the surveyed enterprises consider important. On the basis of the data obtained, the basic descriptive characteristics were calculated, namely the mean, the standard deviation and the coefficient of variation for the whole sample set. Furthermore, enterprises were divided according to the classification questions included for this purpose in the questionnaire. The first classification was based on the number of employees, namely for enterprises up to 250 employees and over 250 employees. The second classification criterion was the field of business activity of the company, according to which five sub-files were created. The third criterion was the country, according to which corporate culture is applied in the enterprise. The enterprises were divided into four sub-sets here. Due to the limited scope of the sample set, some categories are insufficiently represented after classification, but given that, the next planned step of the project is to carry out a quantitative questionnaire survey on a much larger scale. It can be assumed that the categories being monitored are adequately occupied. The planned investigation will take place in a set of randomly selected enterprises, in such a way that it is possible to generalize the acquired knowledge through mathematical and statistical methods.

\section{RESEARCH EVALUTION}

The evaluation of the research was carried out in two successive parts, using content analysis, synthesis and descriptive statistics. The first part was the identification of factors that are associated with the implementation of marketing in the context of Industry 4.0. The second, sequential part, concerned the impacts to which the implementation of these factors leads. The results of the first part of the research were synthesized and the resulting list consisted of 15 attributes, which can be described as fundamental ways of applying marketing innovation in the context of Industry 4.0. The resulting attributes are summarized in Table 1.

Tab. 1 - Marketing innovations associated with Industry 4.0. Source: own

\begin{tabular}{|l|l|l|l|}
\hline 1 & Information terminals & 9 & $\begin{array}{l}\text { Machine-to-machine } \\
\text { (IoT-Internet of Things) }\end{array}$ \\
\hline 2 & $\begin{array}{l}\text { Big data - data processing in the range } \\
\text { of petabytes (1015 bytes) }\end{array}$ & 10 & Marketing for individuals (social media) \\
\hline 3 & Augmented reality & 11 & Corporate Social Responsibility \\
\hline 4 & Virtual cryptocurrency (eg. Bitcoin) & 12 & Cloud storage \\
\hline
\end{tabular}




\begin{tabular}{|l|l|l|l|}
\hline 5 & $\begin{array}{l}\text { Vertical linking of businesses in the } \\
\text { distribution channel }\end{array}$ & 13 & Engagement marketing \\
\hline 6 & Advergaming & 14 & $\begin{array}{l}\text { Buzz marketing: viral, WoM, guerilla } \\
\text { marketing }\end{array}$ \\
\hline 7 & Autonomous distribution & 15 & Mobile marketing ASO - optimization \\
\hline 8 & Additive production (3D Digital Data) & & \\
\hline
\end{tabular}

The list is made up of fifteen factors currently perceived by businesses as 4.0 marketing tools. At the same time, it can be said that it is a combination of technological and non-technological innovations. Therefore, these two groups cannot be strictly separated, as in the OECD manual (2005), where EU Member States established this division. A detailed presentation and explanation of individual factors was carried out in the scientific paper "Innovative Marketing in the context of Industry 4.0". However, this paper primarily presents and analyses the impacts of implementing these factors into business practices.

\subsection{The impacts of marketing innovation implementation}

The outputs from the questionnaire survey were subjected to a content analysis that was participated in by marketing experts and practitioners focusing on the implementation of Industry 4.0 in an enterprise. After a comprehensive analysis of the examined issues, the final synthesis occurred, which resulted in achieving the main objective, compiling the list of impacts resulting from the implementation of marketing 4.0. The resulting list consists of 11 impacts that can be described as the major impacts of applying marketing innovation 4.0. This is followed by the presentation of the individual impacts in Table 2, where the number of responses is presented for the impacts identified. A total of 50 enterprises were involved in the research. The number of responses indicates the number of enterprises reporting the individual impact.

Tab. 2 - Impacts associated with the implementation of marketing innovation in enterprises. Source: own

\begin{tabular}{|l|l|c|c|l|c|}
\hline No. & IMPACT & $\begin{array}{l}\text { Number of } \\
\text { responses }\end{array}$ & No. & IMPACT & $\begin{array}{l}\text { Number of } \\
\text { responses }\end{array}$ \\
\hline 1 & $\begin{array}{l}\text { Building public relations } \\
\text { and branding }\end{array}$ & 23 & 7 & $\begin{array}{l}\text { Increasing the pro- } \\
\text { ductivity of work }\end{array}$ & 15 \\
\hline 2 & $\begin{array}{l}\text { Higher demands on } \\
\text { employees }\end{array}$ & 21 & 8 & $\begin{array}{l}\text { Changing distribu- } \\
\text { tion channels }\end{array}$ & 14 \\
\hline 3 & $\begin{array}{l}\text { Improving communica- } \\
\text { tion with customers }\end{array}$ & 21 & 9 & $\begin{array}{l}\text { Improving the qual- } \\
\text { ity of products }\end{array}$ & 12 \\
\hline 4 & $\begin{array}{l}\text { Increasing competitive- } \\
\text { ness }\end{array}$ & 21 & 10 & $\begin{array}{l}\text { Changes in strategic } \\
\text { planning }\end{array}$ & 10 \\
\hline 5 & $\begin{array}{l}\text { Change in the amount } \\
\text { of costs }\end{array}$ & 20 & 11 & $\begin{array}{l}\text { Changing the corpo- } \\
\text { rate culture }\end{array}$ & 10 \\
\hline 6 & Entering new markets & 15 & \multicolumn{3}{|l}{} \\
\hline
\end{tabular}


Building PR and thereby increasing the value of the business. By implementing Industry 4.0 and marketing innovation into its program, an enterprise exhibits that it has a long-term vision to those around and the stakeholders. Implementation is mostly linked to capital investment, which increases costs but also improves the image and value of the business. This impact is most frequently discovered in the responses, namely for almost half of the enterprises.

Higher demands on employees. Although these are marketing innovations that are classified as non-technological, the impacts of implementation are clearly associated with higher demands on employees. The philosophy of Industry 4.0 will lead to a massive reduction of manual workers and to a high demand of well-educated people. Enterprises are already aware of the need to change the structure of their employees.

Improving communication with customers. The identified marketing innovations lead to better customer knowledge. Thanks to social networks, payment cards and other clues left on the Internet, businesses will have perfect information about each individual. By processing "big data", they can fully understand the behaviour of their customers and tailor the communication mix to suit their needs and achieve greater satisfaction. Improving communication with target audience leads to new customers.

Increasing the competitiveness of a business. Respondents said that the implementation of marketing innovation and Industry 4.0 is in itself a competitive advantage that leads to breaking through in a particular industry compared to other businesses. This is an increase in structural competitiveness resulting from the ownership of property or technology.

Change in the amount of the costs. The enterprises agreed that the implementation of marketing innovation and industry 4.0 is associated with a change in costs. The responses showed that there is no clear justification that an increase in costs will occur, as some businesses have indicated that there is a reduction in costs. The factor of time plays an important role in the cost. In the short term, thanks to the introduction of Industry 4.0, these are costs that, in the long run, lead to cost reductions.

Entering new markets. Businesses, thanks to an innovative approach, gain a competitive edge that is geared towards determining the growth strategy. These growth strategies often refer to entry into new markets. Very often, this is an internationalization of an enterprise that involves technologically advanced countries. However, businesses can expand their operations to other new segments where they have not operated yet, for example from the industrial to the consumer market.

Increasing labour productivity. Labour productivity is increased as a result of the introduction of better technologies. With marketing innovation, the total output that is divided by work inputs increases. Higher productivity leads to higher profits. This profit can then be used in the form of free capital for investments leading to the introduction of further innovations. This cycle is driven by the innovations associated with Industry 4.0.

Changing distribution channels. This is primarily a systemic vertical integration, which leads to the linking of property from production to sales. This state leads to many acquisitions and 
mergers, resulting in the creation of large multinational corporations. Autonomous robotization, especially in engineering, will play a major role in distribution. Industry 4.0 will also lead to the autonomous distribution of goods to the end customer, for example, by means of drones.

Improving the quality of products. Better technology definitely brings an improvement in product quality with it. This is, for example, 3D printing, while preserving the maximum accuracy in product manufacturing. With Industry 4.0, new materials are being used with new features that enhance product quality. The impact of implementation is unambiguously clear on products at a higher price level.

Changes in strategic planning. Implementation of Industry 4.0 leads to changes in long-term business planning. The basic plan of long-term planning is the strategic plan, where mainly the company's vision is changed. Changes also apply to other parts of the strategic plan, which are strategies and tactics. The great importance of digitization is seen by businesses in the control of the strategic plan where, thanks to the processing of big data, an enterprise has a perfect overview of all outputs and hard data in context.

Changing the corporate culture. Corporate culture can be characterized as a way of doing work and dealing with people. These are symbols of a company (abbreviations, slang, the way of dressing, symbols), hero propagation (serves as a model of ideal behaviour), rituals (informal activities, formal meetings) and values that represent the deepest level of corporate culture. Respondents stated that they needed to adapt to these changing market and customer needs as a result of Industry 4.0.

\subsection{Descriptive assessment of the impacts of marketing innovation}

The pilot survey was participated in by 50 respondents who were to assign the level of importance to the proposed impacts of marketing innovation on an order scale from 1 to 6 where 1 insignificance, $6=$ maximum importance. The arithmetic mean, standard deviation and coefficient of variation were calculated from the answers. The impacts presented in Table 3 are ranked by the average value from the most important to the least important.

It is clear from the results of the pilot survey that the respondents consider all of the above impacts to be quite significant. The arithmetic mean of assessing the importance of individual impacts varies from 4.0 to 5.1, and is therefore very high in all cases. The median assessment ranges from 3 to 6 , with the most common median value being 5 , the second highest. In only three cases, for impacts 8,9 and 10, the median is 3 , or 4 , which can be described as mediumhigh importance. These are impacts, which at the same time show low values as well as the arithmetic average of the assessment, which increases the explanatory power of both characteristics. The remaining eight impacts can be labelled as very important on the basis of the median value. Impact 4, i.e. an increase in competitiveness has the highest average and median. 
Tab. 3 - Evaluating the impact of implementing marketing innovation. Source: own

\begin{tabular}{|l|l|l|l|l|l|}
\hline No. & IMPACTS & Mean & Median & $\begin{array}{l}\text { Standard } \\
\text { deviation }\end{array}$ & $\begin{array}{l}\text { Coefficient } \\
\text { of variation }\end{array}$ \\
\hline 4 & Increasing competitiveness & 5.1 & 6 & 1.15 & 0.23 \\
\hline 7 & Increasing the productivity of work & 5.07 & 5 & 0.88 & 0.17 \\
\hline 11 & Changing the corporate culture & 5 & 5 & 1.05 & 0.21 \\
\hline 1 & Building PR, growth in business value & 4.91 & 5 & 1.21 & 0.25 \\
\hline 2 & Higher demands on employees & 4.9 & 5 & 0.97 & 0.2 \\
\hline 3 & $\begin{array}{l}\text { Improving communication with custom- } \\
\text { ers }\end{array}$ & 4.76 & 5 & 1.38 & 0.29 \\
\hline 6 & Entering new markets & 4.67 & 5 & 1.45 & 0.31 \\
\hline 5 & Change in the amount of costs & 4.4 & 5 & 1.31 & 0.3 \\
\hline 9 & Improving the quality of products & 4.4 & 4 & 0.92 & 0.21 \\
\hline 10 & Changes in strategic planning & 4.2 & 4 & 1.4 & 0.33 \\
\hline 8 & Changing distribution channels & 4 & 3 & 1.53 & 0.38 \\
\hline
\end{tabular}

The standard deviation, which indicates the average dispersion of the statistical set values around the arithmetic mean, is the lowest for impacts No. 7, No. 9 and No 2, the highest on the contrary, for impacts No. 8, No. 6 and No. 10. Due to the difference in the level of the values for the individual impacts, the relative variability rate is also used, namely the coefficient of variation, which indicates the dispersion of the values in relation to the average. It ranges from 17 to $38 \%$, with the lowest variability being impacts No. 7, No. 2 and No. 9 or No. 11, the highest relative variability is for impacts No. 8, No. 10 and No. 6. It is clear that for the impacts with the lowest variability, the respondents' agreement in answers is high, while for the impacts with a high degree of variability, the respondents agreed to a lesser degree on the rating. Overall, it can be concluded that the respondents consider all the identified impacts as important, while impacts with very high up to maximum importance are predominant.

\subsection{The influence of the classification of questions on the research results}

The classification questions that were included in the questionnaire allow you to divide enterprises according to different criteria. These are the three following areas: size of the enterprise, the field of business and geographic business culture that is applied in the enterprise. Methods of descriptive statistics were used for evaluation. As already mentioned, the sample set was obtained by deliberate selection, so the mathematical-statistical methods cannot be used for the data obtained. All three classification questions are presented in Table 4. The responses were aggregated into a smaller number of groups so that the groups are large enough and the most objective to compare.

To compare the results, the arithmetic mean and coefficient of variation were used. The first classification question was the size of the enterprise. Here, micro-enterprises, small enterprises and medium-sized enterprises were aggregated into one group. A total of 19 respondents were included in this group. The arithmetic average of the assessment ranges from 3.6 to 5.5, indi- 
cating that all impacts are quite important for these businesses. For two impacts, the average score is less than 4 , only one is higher than 5 . The coefficient of variation is between $11 \%$ and $35 \%$ for small and medium enterprises, therefore the relative variability is relatively different for individual impacts.

Tab. 4 - The effect of classification of respondents' answers to the questions.

Source: own

\begin{tabular}{|c|c|c|c|c|c|c|c|c|c|c|c|c|c|c|}
\hline \multirow[t]{2}{*}{$\dot{z}$} & \multicolumn{2}{|c|}{$\begin{array}{l}0-250 \\
\text { employees, } \\
n=19\end{array}$} & \multicolumn{2}{|c|}{$\begin{array}{l}251 \text { and more } \\
\text { employees, } \\
\mathrm{n}=31\end{array}$} & \multicolumn{2}{|c|}{$\begin{array}{l}\text { Automo- } \\
\text { tive } \mathrm{n}= \\
21\end{array}$} & \multicolumn{2}{|c|}{$\begin{array}{l}\text { other } \\
\text { fields } \mathrm{n} \\
=29\end{array}$} & \multicolumn{2}{|c|}{$\begin{array}{l}\text { CR } \\
n=21\end{array}$} & \multicolumn{2}{|c|}{$\begin{array}{l}\mathrm{EU} \\
\mathrm{n}=19\end{array}$} & \multicolumn{2}{|c|}{$\begin{array}{l}\text { World } \\
\mathrm{n}=10\end{array}$} \\
\hline & $\overline{\mathrm{x}}$ & $\mathrm{CV}$ & $\overline{\mathrm{x}}$ & $\mathrm{CV}$ & $\overline{\mathrm{x}}$ & $\mathrm{CV}$ & $\overline{\mathrm{x}}$ & $\mathrm{CV}$ & $\overline{\mathrm{x}}$ & $\mathrm{CV}$ & $\overline{\mathrm{x}}$ & $\mathrm{CV}$ & $\overline{\mathrm{x}}$ & $\mathrm{CV}$ \\
\hline 1 & 4.8 & 0.31 & 4.9 & 0.23 & 5.0 & 0.17 & 4.2 & 0.35 & 4.6 & 0.31 & 4.4 & 0.25 & 5.7 & 0.08 \\
\hline 2 & 4.0 & 0.25 & 5.2 & 0.16 & 5.3 & 0.13 & 4.2 & 0.18 & 4.4 & 0.23 & 5.6 & 0.09 & 4.5 & 0.33 \\
\hline 3 & 4.6 & 0.16 & 4.9 & 0.27 & 4.8 & 0.29 & 5.0 & 0.16 & 5.1 & 0.15 & 4.8 & 0.24 & 5.3 & 0.18 \\
\hline 4 & 5.0 & 0.20 & 5.1 & 0.23 & 5.7 & 0.08 & 5.0 & 0.23 & 5.4 & 0.13 & 4.6 & 0.29 & 5.7 & 0.08 \\
\hline 5 & 4.6 & 0.29 & 4.5 & 0.29 & 4.5 & 0.29 & 3.3 & 0.35 & 4.6 & 0.24 & 3.3 & 0.28 & 3.7 & 0.34 \\
\hline 6 & 3.6 & 0.34 & 4.9 & 0.28 & 4.7 & 0.31 & 3.1 & 0.28 & 3.5 & 0.32 & 3.4 & 0.16 & 5.3 & 0.31 \\
\hline 7 & 4.6 & 0.20 & 5.1 & 0.16 & 5.1 & 0.16 & 5.0 & 0.20 & 4.7 & 0.20 & 5.5 & 0.27 & 5 & 0.16 \\
\hline 8 & 3.7 & 0.35 & 4.1 & 0.39 & 4.2 & 0.30 & 4.6 & 0.35 & 4.5 & 0.33 & 4.3 & 0.29 & 5.5 & 0.09 \\
\hline 9 & 4.5 & 0.11 & 4.3 & 0.23 & 4.6 & 0.27 & 4.6 & 0.10 & 4.7 & 0.10 & 4.5 & 0.25 & 4.5 & 0.11 \\
\hline 10 & 4.0 & 0.20 & 4.2 & 0.37 & 5.2 & 0.14 & 3.6 & 0.34 & 4.3 & 0.29 & 5.5 & 0.09 & 4.7 & 0.10 \\
\hline 11 & 5.5 & 0.15 & 4.8 & 0.22 & 4.6 & 0.26 & 4.8 & 0.30 & 5.6 & 0.11 & 5.7 & 0.08 & 4.5 & 0.37 \\
\hline
\end{tabular}

The second group is represented by large enterprises where the arithmetic average is between 4.1 and 5.2. In this case, it can also be said that the enterprises consider these impacts to be of considerable importance. Not one average score is lower than 4 , on the contrary, there are three impacts with a higher average than 5 in this group. The coefficient of variation for large enterprises is from $16 \%$ to $37 \%$. When comparing the assessment of the two groups by the arithmetic mean, it is clear that there is a larger range of averages for SMEs. The average SME impact rating starts with lower values, in two cases it is even below 4 . The coefficient of variation of the evaluation peaks slightly in favour of SMEs, for which there are slightly lower values, indicating that respondents agreed more on answers than for large enterprises. Overall, however, no significant differences can be observed between the responses of SMEs and large enterprises based on the sampling data.

The second classification question was related to business. The automotive industry is dominating in the Czech Republic, which is also reflected in the pilot survey, where 21 enterprises are in the automotive field. Other fields, broken down by NACE, were aggregated into one group, as the responses were very diverse. The arithmetic average of assessment ranges from 4.2 to 5.7 in the automotive sector, which means that they assess all impacts as very important. None 
of the impacts has an average of under 4 , while four impacts have an average of over 5 . The coefficient of variation is $8 \%$ to $31 \%$ for the automotive field, so the relative variability is quite different. Enterprises from other industries have an average assessment of 3.1 to 5.0 , with three impacts averaging less than 4 . None of the impacts reached an average of over 5 . The coefficient of variation for other fields ranges from $10 \%$ to $35 \%$. A comparison of automotive and other industries shows that the average impact assessment is higher in the automotive industry than in the automotive industry, which adds importance to the impacts. At the same time, in automotive businesses, greater consistency in the assessment can be observed than in other fields, which demonstrates the lower coefficient of variation values. On the basis of the specified characteristics, significant differences can be observed in the enterprises between the compared groups according to the industry. Automotive enterprises generally consider the impacts of innovative marketing and Industry 4.0 as more important than enterprises in other industries, and match more closely on impact ratings.

The third classification question was the corporate culture, applied in the given business. If the interviewed enterprise has a parent company abroad, it also has the corporate culture of the country of the parent company implemented. The responses were aggregated into three groups. The first group consists of enterprises with Czech corporate culture, of which there are 21. The average rating for enterprises with Czech corporate culture ranges from 3.5 to 5.6. The average rating is less than 4 for only one impact, in three cases, the average is higher than 5 . The coefficient of variation for these enterprises ranges from $10 \%$ to $33 \%$. For enterprises with a European corporate culture, the average rating ranges from 3.3 to 5.7. Two impacts have an average of less than 4 , four impacts have an average rating of more than 5 . The coefficient of variation for European businesses ranges from $8 \%$ to $29 \%$. There are 10 businesses with a global culture, namely enterprises from the USA, Japan, Israel, Russia and Korea. The average rating in this group of enterprises ranges from 3.7 to 5.7. Only one of the impacts has an average rating of less than 4 , for five impacts, the average is higher than 5 . The coefficient of variation is between $8 \%$ and $37 \%$ for enterprises in the rest of the world. A comparison of three enterprise groups according to corporate culture shows that the average impact rating has some differences. The enterprises with a Czech corporate culture have the lowest number of impacts with an average rating of more than 5. On the contrary, the enterprises with a global culture have the most impacts with an average of more than 5 . Concerning the consensus in the ratings measured by the coefficient of variation, this is the highest in the case of enterprises with a European culture.

\section{DISCUSSION}

The results obtained may be compared with research conducted abroad, which focuses on the same objectives in a different environment. It is important to bear in mind that the research presented here is a pilot research in a new area of the economy. Even so, it is interesting to compare the results with the opinions of the renowned American economist Rifkin (2016), according to whom Industry 4.0 will see production with near zero marginal costs, which will result in overall savings on costs. In practice this means that the highest production-related costs will be those needed to install production facilities. However, the research did not conclusively confirm Rifkin's claim. The results of the research show that Czech companies are in agreement as re- 
gards the change in costs, but they are no longer able to agree as to whether total costs will be increased or reduced. Overall, it is possible to confirm that in the short term, the total costs are increasing, which in the long run will lead to a reduction in total costs. The authors Anna \& Fang (2016) in the Journal of the Academy of Marketing Science published by Springer presented the results of a similar research in which they determined eight fundamental impacts. These impacts were specified in the literature review. If both research results are compared, five of the impacts are the same: changes in strategic planning, higher product quality, higher work productivity and increased business competitiveness. The other impacts differ due to the place in which the research was carried out, with the research we compared having been conducted on the market outside Europe. There was a complete match when compared with the research by the authors Jeng \& Pak (2016). The research in the Czech Republic and the research in the USA showed differences in the impacts on businesses of varying sizes. Large firms in the USA and ČR are prospering far more from the use of marketing innovations.

\section{CONCLUSION}

The main objective of the paper was to identify the impacts of marketing innovations on competitiveness in connection with Industry 4.0 in business practice. The paper is based on a literature overview, but it should be noted that the subject is so progressive that there is not enough valid information. Most technical literature refers to technical innovations in Industry 4.0, not to marketing innovations and their impacts. Marketing innovation plays an equally important role as product innovation. This state of affairs was the cause of a project that seeks to capture changes in this area. The paper follows up on the first part of the project identifying the list of 15 marketing innovations associated with Industry 4.0 presented in Table 1. This was followed by primary research addressing the impacts of these identified innovations. The research was a combination of qualitative research, where 11 impacts were identified by enterprises as the impacts of Industry 4.0 implementation. The results revealed several differences between the responses of enterprises and views arising from research. Two major differences are in the view of employment and the change in costs that are contained in the discussion chapter. In summary, however, it can be said that the resulting list of 11 impacts is a reflection of views of the enterprises that present the use of Industry 4.0. Subsequent frequency ratings confirmed that the businesses identified all impacts as important. Increasing competitiveness was clearly the best-rated impact. This can be explained by the fact that marketing innovations provide a better understanding of customer needs. Through the online connection, these needs are immediately implemented directly into the creation of the product or directly onto the production line. This enables individual needs to be satisfied at the price of large-scale production. This can greatly boost productivity and, in the final phase, ensure greater competitiveness. Part of the frequency evaluation were the effects of the classification questions. If the size of an enterprise is taken into consideration, large enterprises place greater emphasis on the impacts than small and medium-sized enterprises. At the same time, there is a bigger consensus of opinion among large enterprises. The reason is that large multinational corporations are quicker to embrace digital technologies and processes, and SMEs are lagging behind in their digital transformation due to pressure on investment. 
The second classification question was the industry where automotive companies place more importance on the impact of Industry 4.0, while in automotive companies, there is a greater consensus of opinion in the ratings than for other sectors. The reason can be seen in Germany which has bet on extensive digitization and the use of robots. Czech businesses are linked with German enterprises in many cases in terms of property or in supply-customer relationships. The main area of cooperation between the two countries is the automotive manufacturing industry. The third classification question was the country of corporate culture, where enterprises with German corporate culture stated the greatest importance, but thanks to the aggregation of results, the enterprises with a global corporate culture placed the highest importance on the impacts, followed by European corporate culture, while Czech enterprises gave them the lowest importance. However, the differences in rating were minimal due to the current globalization and interconnection of the world. It is also important to emphasize that foreign investors do not have a tendency to invest in top-quality workplaces in the Czech Republic and it is more assembly centres that are arising there. They do not require such extensive reinvestment and qualified workforce as research facilities, and therefore the profits generated flow to the mother countries of the companies.

Finally, it is possible to state that the pilot research has been successfully carried out in an area about which the entire professional world is speaking, but which is practically not mapped out in the field of marketing innovations. The reason is the complexity of the environment and the stunning development in the field of digitization. The conducted research must be taken as a pilot project that wanted to name the impact of marketing innovations associated with Industry 4.0. The identified impacts will then be subjected to massive primary research by using "random selection" of respondents so that statistical induction methods could be used. Despite this, the main objective of the paper has been fulfilled. It has been empirically proven that innovative marketing implemented in the context of Industry 4.0 clearly makes enterprises more competitive.

\section{References}

1. Aksoy, H., \& Cengiz, E. (2016). Innovative marketing in SMEs and large scale enterprises: gaziantep sample. Economic and Social Development: Book of Proceedings,Varazdin. Retrieved July 27, 2017, from https://search.proq uest.com/docview/ 1793195821 ? accountid $=17116$.

2. Anna S. C. \& Fang W. (2016). Utilizing customer knowledge in innovation: antecedents and impact of customer involvement on new product performance. Journal of the Academy of Marketing Science, 44 (4), 516-538. http://dx.doi.org/10.1007/s11747-015-0433-x.

3. Cummins, D., Gilmore, A., O’Donnell, A. \& Carson, D. (2000). Innovation marketing in SMEs a conceptual and descriptive framework. New Product Development and Innovation Management, 21 (2), 227-244.

4. ČNOPK. (2016). Čtvrtá průmyslová revoluce. Magazín o primyslové automatizaci a robotice. Retrieved September 22, 2017, from https://factoryautomation.cz/.

5. Č́SÚ. (2016). Inovace v ČR. Retrieved September 30, 2017, from https://www.czso.cz/. 
6. Fischer, R. (2017). Čtvrtá průmyslová revoluce. Magazin o priomyslové automatizaci a robotice. Retrieved September 22, 2017, from https://factoryautomation.cz/.

7. Ghezzi, A., Balocco, R., \& Rangone, A. (2016). The open innovation - strategy nexus: Findings from the mobile telecommunications industry. Management Research Review, 39 (5), $569-598$.

8. Hommerová, D. \& Patrovský, Š. (2017). Assessing the level of CRM in the bennlich company using the crack Metod. Opportunities and Threats to Current Business Management in Crossborder Comparison. (pp. 48-58). Chemnitz: Verlag der GUC.

9. Chen, S. \& Pao, Ch. (2017). Marketing Innovation. ACM, 2017. (pp. 12-17). Taiwan. http://doi.org/10.1145/3107514.3107517.

10. Churwiruch, N., Jhundra-Indra, P., \& Boonlua, S. (2015). Marketing Innovation Strategy and Marketing performance: a conceptual framework. Allied Academies International Conference. Academy of Marketing Studies, 20 (2), 82-93.

11. Jáčová, H. \& Horák, J. (2015). Communications in computer and information science. New York: Springer Publishing.

12. Jeng, D. J. F. \& Pak, A. (2016). The variable effects of dynamic capability by firm size: the interaction of innovation and marketing capabilities in competitive industries. International Entrepreneurship and Management Journal, 12 (1), 115-130. https://doi.org/10.1007/s11365-014$0330-7$.

13. Junge, M., Severgnini, B \& Sørensen, A. (2016). Product-Marketing Innovation, Skills, and Firm Productivity Growth. Review of Income and Wealth, 62 (1), 724-757. https://doi:10.1111/ roiw.12192.

14. Kamp, B., \& Parry, G. (2017). Servitization and advanced business services as levers for competitiveness. Industrial Marketing Management, 60, 11-16. doi:10.1016/ j.indmarman.2016.12.008

15. Kleindl, B., Mowen, J. \& Chakraborty, G. (1996). Innovative market orientation and alternative strategic orientation in marketing. Entrepreneurship Interface, Conference Proceedings, Chicago: University of Illinois.

16. Korbel, P. (2016). Průmyslová revoluce 4.0. Retrieved January 9, 2017 from: http://byznys. ihned.cz/c1-64009970-prumyslova-revoluce-4-0za-10-let-se-tovarny-budou-ridit-samy-aproduktivita-vzroste-o-tretinu.

17. Kotler, P. \& Bes, F. T. (2005). Inovativní marketing: jak kreativním myšlením vitézit u zákazníkù. Praha: Grada publishing.

18. Lee, R., Lee, J. H. \& Garrett T.C. (2017). Synergy effects of innovation on firm performance. Journal of Business Research, 11 (1) https://doi.org/10.1016/j.jbusres.2017.08.032.

19. Magrath, A. J., \& Higgins, J. M. (1992). Six pathways to marketing innovation; the valueadded analysis: A seventh pathway to marketing innovation. Planning Review, 20 (6), 12-20.

20. Mař́k, V. (2016). Primysl 4.0: výzva pro Českou republiku. Praha: Management Press.

21. Moreira, J., Silva, M. J., Simoes, J. \& Sousa,G. (2012). Marketing Innovation: Study of Determinants of Innovation in the Design and Packaging of Goods and Services- 
Application to Portuguese Firms. Contemporary Management Research, 8 (2), 117-129. http:// dx.doi.org/10.7903/cmr.11047.

22. MPO. (2016). Národní iniciativy Průmysl 4.0 Available from: Retrieved September 15, 2017, from https://www.mpo.cz/cz/prumysl/ zpracovatelsky-prumysl/prumysl-4-0-mav-cesku-sve-misto--176055/.

23. Muangkhot, S., \& Ussahawanitchakit, P. (2015). Strategic marketing innovation and marketing performance. 6th International Trade and Academic Research Conference pp. 7(1), 189-200.

24. Muntzová, A. \& Středula, J. (2016). Komu seberou práci roboti? Retrieved May 11, 2017, from:https://zpravy.aktualne.cz/ekonomika.

25. Novotová, J. (2017). Attributes that define the category of consumer fashion brand from customer's point of view. Ad Alta: Journal of Interdisciplinary Research, 7, (1). 125-132.

26. OECD - Organisation for Economic Cooperation and Development. (2005). Oslo Manual: Guidelines for Collecting and Interpreting Innovation Data, 3rd Edition. Retrieved July 11, 2017 from: http://www.oecd.org/sti/inno/oslomanualguidelines forcollectingandinterpretinginnovationdata3rdedition.htm.

27. Özen, Ü., \& Bingöl, M. (2007). Isletmelerde bilisim teknolojileri ve yenilikcilik: erzurum,erzincan ve ayburttaki kobilerde bir arastirma. Atatürk Üniversitesi. Retrieved June 11, 2007, from: http://e-dergi.atauni.edu.tr/ataunisosbil/article/view/102 0000450/1020000444.

28. Pitra, Z. (1997). Inovační strategie. Praha: Grada publishing.

29. Prahalad, C. K. \& Ramaswamy, V. (2004). Co-Creation Experiences: The Next Practice in Value Creation. Journal of Interactive Marketing, 18 (3), 5-14. https://doi.org/10.1002/ dir.20015.

30. Rifkin, J. (2016). How the third industrial revolution will create a green economy. New Perspectives Quarterly, 33 (1), 6-10. https:/doi.org/10.1111/npqu.12017.

31. Shuba, S. (2016). Paths to and off purchase: quantifying the impact of traditional marketing and online consumer activity. Journal of the Academy of Marketing Science, 44 (4), 440-453. https://doi.org/10.1007/s11747-015-0431-z.

32. Son, J., Sadachar, A., Manchiraju, S., Fiore, A. M., \& Niehm, L. S. (2012). Consumer adoption of online collaborative customer co-design. Journal of Research in Interactive Marketing, 6(3), 180-197. doi:10.1108/17505931211274660

33. Sojková, L. (2017) Is the Czech Republic Preparing for Society 4.0. Liberec Economic Forum. Retrieved September 11, 2017 from: http://www.lef-tul.cz/sekce/LEF_2017.pdf.

34. Suraksha G. N. at al. (2016) Marketing innovation: A consequence of competitiveness. Journal of Business Research, 69 (12), 5671-5681 doi.org/10.1016/j.jbusres.2016.02.042.

35. Ungerman, O. \& Dědková, J. (2017). Innovative Marketing in the Context of Industrie 4.0. Liberec Economic Forum. Retrieved September 11, 2017, from http://www.lef-tul. cz/sekce/LEF_2017.pdf. 
36. Wang, S. at al. (2016). Towards smart factory for industry 4.0. Computer Networks, Elsevier, 10 (1), 158-168. https://doi.org/10.1016/j.comnet.2015.12.017.

\section{Contact information}

Ing. Otakar Ungerman, Ph.D.

Technical University of Liberec

Faculty of Economy

Department of Marketing and Trade

Crech Republic

E-mail: otakar.ungerman@tul.cz.

Ing. Jaroslava Dedkova, Ph.D.

Technical University of Liberec

Faculty of Economy

Department of Marketing and Trade

Crech Republic

E-mail:otakar.ungerman@tul.cz.

Ing. Katerina Gurinova, Ph.D.

Technical University of Liberec

Faculty of Economy

Department of Marketing and Trade

Crech Republic

E-mail: otakar.ungerman@tul.cz. 